\title{
РЕПРЕЗЕНТАЦИЯ ИМИДЖА УДМУРТИИ В ИНОЯЗЫЧНОМ МЕДИАПРОСТРАНСТВЕ (НА МАТЕРИАЛЕ НЕМЕЦКИХ ПУБЛИЦИСТИЧЕСКИХ ИЗДАНИЙ)
}

\author{
Юшкова Людмила Анатольевна \\ д.ф.н., доцент \\ Удмуртский государственный университет
}

\begin{abstract}
Аннотация: В статье представлены результаты исследования, которое позволило оценить формируемый в зарубежных средствах массовой информации имидж Удмуртской республики и сделать выводы о возможностях и способах продвижения современной Удмуртии на медийном рынке, которые могли бы помочь преодолеть процессы негативизации внешнего имиджа Удмуртии и усилить его позитивные стороны.
\end{abstract}

Ключевые слова: Имидж региона, контент-анализ, медиаресурс, медиатекст, стереотип.

\section{REPRESENTATION OF THE IMAGE OF UDMURTIA IN FOREIGN LANGUAGE MEDIA SPACE (BASED ON GERMAN PUBLICATIONS)}

\section{Ludmila Yushkova}

Abstract: The study made it possible to assess the image of the Udmurt Republic formed in foreign media and draw conclusions about the opportunities and ways of promoting modern Udmurtia in the media market, which could help overcome the processes of negating the external image of Udmurtia and strengthen its positive aspects.

Key words: Image of the region, content analysis, media resource, media text, stereotype.

Проведенное исследование посвящено одной из самых актуальных тем в современной лингвистике - изучению механизмов конструирования, развития и трансформации имиджа региона в современном медиадискурсе.

Цель представленного в статье анализа заключалась в том, чтобы реконструировать составляющие внешнего имиджа Удмуртской республики и 
выявить стереотипы, которые репрезентируют внешний имидж Удмуртии, представленный в текстах иностранных (немецкоязычных) он-лайн-изданий. Кроме того, были выявлены доминирующие в рамках дискурса об Удмуртии темы, вызывающие наибольший интерес для немецких СМИ.

Ведущими методами исследования были выбраны метод анализа контента информационных ресурсов на немецком языке, стилистический и контекстуальный анализ текстов.

Материалом для исследования послужили электронные публикации информационных немецких СМИ об Удмуртии: Der Spiegel, Frankfurter Allgemeine Zeitung, TAZ, Die Welt, Deutsche Welle, Die Zeit, Berliner-Zeitung, Hamburger Abendblatt, и других.

Анализ контекстов корпуса письменных текстов БерлинскоБранденбургской академии наук (DWDS-Corpus) показал, что Удмуртская республика практически не представлена в материалах таких авторитетных немецких публицистических изданий как „Die Zeit“, „Tagesspiegel“ и „Berliner Zeitung“. За период с 1994 встретилось всего два упоминания об Удмуртии в газете „Tagesspiegel“ и пять упоминаний в газете „Berliner Zeitung“. В материалах газеты „Die Zeit“ с 1994 по 2018 год Удмуртия упоминалась 30 раз.

Семантическое пространство дискурса немецких СМИ об Удмуртии имеет несложную структуру: политический дискурс, экономический дискурс, Военный дискурс и дискурс личности М.Т. Калашникова, культурный дискурс.

Несмотря на то, что Удмуртская республика и связанные с ней события, факты и персоналии редко упоминаются в рассмотренных источниках, можно выделить некоторые темы, которые относительно регулярно освещаются в материалах немецкоязычной прессы. Они в большей степени влияют на формирование внешнего имиджа и восприятие Удмуртии, формируя устойчивые стереотипы.

Термин «стереотип» используется в исследовании для обозначения «распространенных в общественном мнении предвзятых представлений о членах различных национально-этнических, социально-политических и профессиональных групп» [Липпман 2004: 96]. С одной стороны, СМИ активно влияют на формирование общественного мнения, с другой стороны, материалы СМИ служат показателем того, какие стереотипы существуют в сознании представителей конкретного социокультурного сообщества. 
Результаты контент-анализа содержания соответствующих статей в упомянутых выше изданиях позволяют сделать вывод, что наиболее распространенные стереотипы в отношении Удмуртии, получившие отражение в иностранной прессе, связаны с темой военно-промышленного комплекса. Данная тема затрагивается в материалах следующего содержания:

1. Тяжелая болезнь и смерть М.Т. Калашникова: „Nach schwerer Krankheit sei Kalaschnikow am Montag in Ischewsk gut 1000 Kilometer östlich von Moskau gestorben, teilte der Sprecher der Regierung der russischen Teilrepublik Udmurtien, Viktor Tschulkow, mit" [Russische Legende: Waffenkonsrukteur Michail Kalaschnikow ist tot // Die Zeit, 23.12.2013 (on/line)].

2. Пожар на складе боеприпасов в Пугачево: Mehrere Lagerhäuser auf dem Stützpunkt in der Teilrepublik Udmurtien an der Wolga standen in Flammen [Feuer in russischem Armeedepot // Die Zeit, 3.06.2011 (on-line)].

3. Разработка нового логотипа удмуртскими оружейниками: „Die Waffenschmiede aus Udmurtien westlich des Uralgebirges stellten ein neues Logo vor" [Sportkleidung und Waffen mit Kalaschnikow-Logo // Die Zeit, 2.12.2014 (on/line)].

К наиболее активно освещавшимся в немецких СМИ темам относятся также следующие темы:

- Победа на «Евровидении» коллектива из Удмутии: «Бурановские бабушки: Die Buranowskije Babuschki aus der Wolga-Region Udmurtien mit ihren roten Trachten, Kopftüchern und Bastschuhen sind mit der Ethno-Pop-Nummer «Party for Everybody» längst Kult in Baku [Russland und Irland im ESC-Finale // Die Zeit, 23.05.2012 (on/line)].

- Уничтожение химического оружия: "Die aufwendige Zerstörung des russischen Chemiewaffenarsenals geht auf Kosten der deutschen Steuerzahler" [Schlindwein S. Russische Chemiewaffen: Giftiges Erbe des Kalten Kriegs // Spiegel on-line URL: http://www.spiegel.de/wissenschaft/mensch/russische-chemiewaffengiftiges-erbe-des-kalten-kriegs-a-560211.html].

Тема удмуртской культуры, самобытности удмуртского народа, удмуртского языка и природы отдельно не поднимается. Эта тема затрагивается только в связи с освещением каких-либо культурных мероприятий с участием удмуртских исполнителей (фестиваль Рантакала, Евровидение).

Изучив спектр тем и содержание статей об Удмуртской республике, представленных в англоязычном информационном пространстве, удалось 
выяснить, что в большинстве случаев приходится сталкиваться с негативными стереотипами в экономическом и военно-промышленном дискурсе («УР работает на оборонку», «слишком много оружия», «депрессивный регион») или с деструктивными образами в политическом дискурсе («манипуляции во время предвыборной кампании»): „In der Teilrepublik Udmurtien bot der Verwaltungschef der Stadt Ischewsk jedem Veteranen einen einmaligen Bonus auf die Monatsrente an, wenn sie für die Partei von Regierungschef Wladimir Putin stimmen [Viele Klagen über Wahlmanipulationen in Russland // Die Zeit, 4.12.2011 (on-line)].

Важно также подчеркнуть, что, судя по содержанию изученных публикаций, Удмуртия не существует в немецком социокультурном сообществе как самостоятельный политический, социально-экономический или культурный субъект. Упоминания Удмуртской республики в западной прессе связаны, в основном, с событиями, имеющими общероссийскую значимость (экспорт оружия как одна из важных сфер российской экономики, Калашников как личность общероссийского масштаба, участие удмуртских политиков в политических мероприятиях российского уровня (например, выборы президента РФ)). Республика Удмуртия воспринимается и репрезентируется немецкими СМИ практически исключительно в общероссийском контексте. Это проявляется, в частности, в том, что вместо названия региона обычно употребляется его географическое положение внутри России (Republik an der Wolga, Teilrepublik Russlands).

Таким образом, гипотеза исследования о том, что внешний имидж Удмуртии, которая длительное время была закрытой республикой, базируется, в основном, на отрывочных стереотипных представлениях, часто негативных, подтвердился. Удмуртия в немецких СМИ представлена очень незначительно, a, исходя из содержания проанализированных материалов, внешний имидж региона следует характеризовать как несформированный и стихийный. Современная Удмуртия нуждается в целенаправленном продвижении на медийном рынке, которое поможет преодолеть процессы негативизации внешнего имиджа Удмуртии и усилить его позитивные стороны. 


\section{Список литературы}

1. Липпман У. Общественное мнение. - M., 2004. - C. 96.

2. Das Digitale Wörterbuch der deutschen Sprache (DWDS) [Электронный pecypc] // Projekt der Berlin-Brandenburgischen Akademie der Wissenschaften. URL: http://www.zeit.de/index (дата обращения 14.07.2014). 